\title{
EFFICACY OF DIFFERENT LEVELS OF DRIED DISTILLER'S GRAINSWITH SOLUBLES AS A REPLACEMENT FOR SOYBEAN MEAL AND PORTION OF THE CORN IN A GROWING AND FINISHING BAFFALO CALVES DIET
}

\author{
M.M. El-Shinnawy ${ }^{1}$; K.E.I. Etman ${ }^{2}$; Gihan M. El- Moghazy ${ }^{3}$ and A.M. El-Shinnawy ${ }^{3}$ \\ ${ }^{1}$ Anim. Prod. Dept., Faculty of Agric., Mansoura Univ., Egypt. \\ ${ }^{2}$ Animal Production Research Institute, Ministry of Agric., Dokki, Giza, Egypt. \\ ${ }^{3}$ Regional Center for Food and Feeds, Agric. Res. Center, Giza, Egypt.
}

\section{SUMMARY}

$\mathrm{E}$ ighty growing buffalo calves, 14-16 months old, with an average weight of $202 \mathrm{~kg}$, were divided, randomly, into four equal experimental groups, (20 calves each), and used to investigate the effect of replacing $0 \%, 10 \%, 20 \%$ and $30 \%$ of soybean and yellow corn by dried distiller's grains with soluble (DDGS) in total mixed rations (TMR) (1,2,3 and 4, respectively). The experimental diets were nearly similar in crude protein (CP) (iso-nitrogenous) and total digestible nutrients (TDN) (iso-caloric). All animals were fed daily $3 \%$ of live body weight and the trial lasted for 180 days. Metabolism trials were carried out on three mature rams for each TMR to estimate nutrient digestibilities, nutritive values and nitrogen balance. The economic efficiency was also calculated. Significantly lower values of live body weight and daily gain were recorded for calves fed the control diet (TMRI). Significantly best values were achieved by calves fed the $30 \%$ followed by $20 \%$ dietary DDGS instead of soybean meal and yellow corn. Results of digestibility trials indicated that rams fed the control diet (TMRI) had significantly $(\mathrm{P}<0.05)$ lower digestibility coefficients, nutritive values and nitrogen utilization compared with other diets. No significant differences were observed $(\mathrm{P}<0.05)$ among the experimental groups in ruminal $\mathrm{pH}$ and the obtained values were within the normal ranges (6.70-6.84). Ammonia-N concentration was greater in control diet but, there was a linear decrease in ammonia-N concentration as the level of DDGS increased in the diets. Supplemented rations with DDGS showed significant increase in the level of TVFA's. Increasing level of DDGS in diets of calves' increased TP concentrations, being the lowest in TMRI (control), while albumin and globulin recorded insignificant differences among all diets. The values of AST were higher significantly $(\mathrm{P}<0.05)$ in rations containing DDGS than that of control. Values of serum- creatinine and cholesterol were not affected by dietary treatments. Blood parameters studied indicated normal physiological and healthy status of all experimental calves. Total body gain and daily gain were increased quadratically $(\mathrm{P}<0.05)$ with increasing DDGS replacement. Calves fed diets containing $20 \%$ or $30 \%$ DDGS recorded the best feed conversion values followed by $20 \%$ DDGS.

It may be concluded that inclusion of DDGS with a rate of $30 \%$ from soybean meal and yellow corn in buffalo calves diet result in better net revenue, economical efficiency and feed cost per kg daily gain.

Keywords: DDGS, digestibility, nutritive values, nitrogen utilization, rumen fermentation, growth performance and economic efficiency.

\section{INTRODUCTION}

Starch in grains, during processing, is converted into ethanol and carbon dioxide. The rest of the grain constituents are: proteins, lipids, minerals and vitamins. These compounds, relatively are unchargeable chemically, but concentrated approximately in threefold, (Spiehs et al., 2002). Distiller's grains are considered to be good source of energy and protein for ruminants (Warner, 1970). They are low in lignin and starch, and high in digestible natural fiber compared to original corn grains as reported by Gilbery et al. (2004). They contain other nutrients recovered from fermented grains. These include low soluble carbohydrates, relatively high fiber, high fat, and a factor stimulating cellulose digestion in the rumen (Hach, 1993).

Feeding DDGS supply animals with both crude proteins and energy. Liu et al. (2006) reported that DDGS contains are considered valuable source of supplemental proteins with high rumen undegradable $47 \%$ of crude protein (bypass protein) as compared to $35 \%$ in soybean meal. Kleinschmit et al. (2006) 
proposed that by-pass protein is necessary for maximal production by young growing ruminants and high producing dairy cows. It may be due to escape protein value improving the protein status of animal resulting in superior performance or improved rumen fermentation which results in better utilization of feedstuffs (Stein and Shurson, 2009).

Powers et al. (1995), reported that DDGS as proteins source are often more economical than soybean meal or other oilseed meals. Sheep can be fed on greater concentration of DDGS, (Schower et al., 2008), without affecting animal performance. Huls et al. (2006) reported that DDGS can be used up to $22.5 \%$ of fattening ration with no negative effect on performance.

The objectives of the current study were to determine the effects of partial replacement (10, 20 and $30 \%$ ) of soybean meal and portion of yellow corn by DDGS on DM intake, digestion coefficients, rumen and blood parameters and growth performance, economic efficiency of growing and finishing buffalo calves.

\section{MATERIALS AND METHODS}

The experiment was carried out at Toukh Feedlot Station, kalyobia governorate and Regional Center for Food and Feed (RCFF), Agricultural Research Center, Ministry of Agriculture.

Eighty buffalo calves of 14-16 months age, with an average initial live body weight of $202 \mathrm{~kg}$, were divided into four similar groups in live body weight and age (20 animals each). Buffalo's body weights were recorded at the beginning of the experimental and morning before feeding every month thereafter, till the end of the trial that lasted for 180 days. Each group was kept in separate shaded pen.

\section{Experimental diets:}

Four iso-nitrogenous and iso-caloric, total mixed rations (TMR) were formulated. One of the TMR served as control and three were formulated to contain 0, 20 and 30\% DDGS in place of 0, 33, 66 and $100 \%$ of soybean meal and 0, 12.5, 25 and 37.5\% from yellow corn. Composition of tested rations are presented in Table (1). The animals were randomly assigned to receive one of the four TMR. All animals were fed $3 \%$ of body live weight TMR in two equal meals, twice daily (8.00 am and $3.00 \mathrm{pm})$. Fresh water and salt blocks were available for each group throughout all the day.

Table (1). Feed ingredients of the experimental total mixed rations (TMR) on dry matter basis.

\begin{tabular}{lcccc}
\hline Feed ingredients, $\%$ & Control & $\begin{array}{c}10 \% \\
\text { DDGs } \\
\text { TMR2 }\end{array}$ & $\begin{array}{c}20 \% \\
\text { DDGS } \\
\text { TMR3 }\end{array}$ & $\begin{array}{c}30 \% \\
\text { DDGS } \\
\text { TMR4 }\end{array}$ \\
\hline Yellow corn & TMR 1 & 35.0 & 30.0 & 25.0 \\
Soybean meal (44\%) & 15.0 & 10.0 & 5.0 & 0.0 \\
Wheat bran & 7.0 & 7.0 & 7.0 & 7.0 \\
Dried distiller grains with soluble & - & 10.0 & 20.0 & 30.0 \\
Berseem hay & 30.0 & 30.0 & 30.0 & 30.0 \\
Molasses & 5.0 & 5.0 & 5.0 & 5.0 \\
Lime stone & 1.5 & 1.5 & 1.5 & 1.5 \\
Salt & 1.0 & 1.0 & 1.0 & 1.0 \\
Mineral premix & 0.5 & 0.5 & 0.5 & 0.5 \\
\hline
\end{tabular}

\section{Metabolizable trials:}

Four metabolizable trials were carried out, to evaluate the experimental rations, using three mature Rahmany rams, aged 28 months and weighing $60 \mathrm{~kg}$ live weight, for each diet. The animals in each trial, were fed individually in metabolic cages on one of the $4^{\text {th }}$ TMR rations to provide animals with their maintenance requirements of mature sheep according to NRC (1985).

Each trial lasted 31 days ( 21 days as preliminary period, followed by 10 days as collection period), during the collection period feces and urine were collected daily. One tenth of daily feces and excreted urine were taken. Urine samples were stored in tight bottles containing sulphuric acid (1:1) to capture $\mathrm{NH}_{3}$ nitrogen.

The collected feces ( 10 days collection) of each animal was well mixed and then dried at $60^{\circ} \mathrm{C}$ for 48 hours. Samples were taken for determination of dry matter. The remaining feces were ground for proximate chemical analysis. 
The representative samples of different TMR, feces and urine were chemically analyzed according to the official of A.O.A.C. (1995) methods. Fiber constituents: neutral detergent fiber (NDF) was determined, according to Van Soest and Marcus (1964). Acid detergent fiber (ADF) and acid detergent lignin (ADL) were determined by Robertson and Van Soest procedures (1981). Non fibrous carbohydrates were calculated according to Calsamiglia et al. (1995).

\section{Rumen liquor parameters:}

After the end of each metabolism trial, rumen liquor samples were taken from the animals through stomach tube. Samples were taken just before morning feeding, then at 2, 4 and 6 hours, post feeding. Collected rumen liquor samples were directly tested for $\mathrm{pH}$ using Orian 680 digital $\mathrm{pH}$ meter. Samples were strained through four layers of cheese cloth for each sampling time to get clear liquid. Ammonia nitrogen $\left(\mathrm{NH}_{3}-\mathrm{N}\right)$, was determined using magnesium oxide $(\mathrm{MgO})$, as described by AL- Rabbat et al. (1971). Total volatile fatty acids (VFA'S) concentrations were estimated, using steam distillation methods (Warner, 1964).

\section{Blood parameters:}

At the end of growth trials, blood samples were collected from the Jugular vein of randomly 3 animals, for each treatment at zero time before morning feeding in heparinized test tube. The blood plasma was obtained by centrifuging the blood samples soon after collection at $4000 \mathrm{rpm}$, for 15 minutes. Blood plasma was transferred into a clean dried glass vials, then stored in deep freezer at $-20^{\circ} \mathrm{C}$, for subsequent specific chemical analysis. Total protein was determined as described by the method of Weichselbaum (1989) and albumin according to Doumas et al. (1971). Globulin concentration was calculated as the difference between serum total protein and albumin. Serum creatinine was conducted according to Bartels (1971). Aspartate aminotransferase (AST) and alanine aminotransferase (ALT), were determined as described by Reitman and Frankel (1957). Cholesterol (mg/ $100 \mathrm{ml}$ plasma) was determined according to Trinder (1969). Plasma triglycerides were determined according to the method of Fossati and Prencipe (1982).

\section{Statistical Analysis:}

Data was statistically analyzed using SAS (2003): When F-test was positive, the differences between means were determined according to Duncan (1955).

\section{RESULTS AND DISCUSSION}

\section{Evaluation of DDGS and the experimental TMR:}

The chemical composition of DDGS and the four TMR (table 2) indicated that DDGS contained $26.93 \%$ crude protein (CP), $9.88 \%$ ether extract (EE), $10.74 \%$ crude fiber (CF), $4.58 \%$ ash and $47.87 \%$ nitrogen free extract (NFE), the crude protein value of DDGS was close to that reported by Choi et al. (2008), being 27.53 and lower than that recorded by Spiehs et al. (2002), being 30\%, ether extract value of DDGS was almost similar to that reported by NRC (2000).

Such differences could be mainly due to processing technological conditions, crude fiber content (CF) of DDGS was higher than that reported by Lumpkins et al. (2004). Also NDF content of DDGS was 37.78\%, in agreement with that of Spiehs et al. (2002) who reported that NDF of DDGS ranged between 37 to $48 \%$. The present result led to decreasing NDF and hemicellulose linearly with increasing DDGS in the diet.

The chemical composition of the experimental rations showed approximate values except TMR1, which had the lowest CF and highest NFE contents compared to the other rations. These results may be attributed to the high CF and low NFE content of DDGS, when compared with yellow corn and soybean meal. The non-fibrous carbohydrates (NFC) ranged from 39.28-41.68\% in the present experimental rations. The values are more close to the values obtained by Calsamiglia et al. (1995), who stated that rations formulated for 35 to $42 \%$ NFC (DM basis), should avoid metabolic disturbances related to feeding high levels of starches in grains.

\section{Digestibility coefficient and nutritive values:}

The nutrients digestibility coefficients and nutritive values of experimental rations are represented in Table 3. Dry matter $(\mathrm{DM})$ and organic matter $(\mathrm{OM})$ digestibilities were lowest $(\mathrm{P}<0.05)$ for control ration than other diets. These results are in contrast with those obtained by Pavan et al. (2007), who reported that a linear decrease in apparent total tract digestibility of DM and OM in response to increasing DDGS supplementation in rations for steers. Higher digestion coefficient of $\mathrm{CP}$ was obtained $(\mathrm{P}<0.05)$, for ration 3 and 4, followed by ration 2 and then control one with significant differences among the four 
treatments. These results are in harmony with those obtained with leupp et al. (2012), who found that total tract $\mathrm{CP}$ digestion was increased with increasing DDGS in the diet. In the present study, as dietary DDGS inclusion rates, CF content was also increased for diet containing 10, 20 and 30\% DDGS. Accordingly this leads to improvement in CF digestibility. The highly digestible fiber in corn DDGS allows it to serve as a partial replacement for forages and concentrates in diets for beef cattle. The present results in Table 3, indicated that nutritive values as TDN and DCP were increased significantly $(\mathrm{P}<0.05)$ with animals fed rations containing DDGS. Moreover, animals fed on control rations recorded the lowest value $(\mathrm{P}<0.05)$.

Generally, adding DDGS at a level of $30 \%$ increased digestibility coefficients and nutritive values of these rations. Therefore, DDGS may be used successfully up to $30 \%$ of the content of the diet. These results are in agreement with $\mathrm{t}$

Table (2). Chemical composition and fiber fractions of DDGS and experimental TMR's (on dry matter basis).

\begin{tabular}{cccccc}
\hline Composition of DM \% & TMR1 & TMR2 & TMR3 & TMR4 & DDGS \\
\hline Dry matter (DM) & 89.51 & 89.33 & 89.15 & 89.41 & 89.67 \\
Organic matter(DM) & 94.22 & 94.17 & 94.12 & 94.07 & 95.42 \\
Crude protein (CP) & 14.05 & 14.10 & 14.20 & 14.25 & 26.93 \\
Crude fiber (CF) & 9.78 & 10.33 & 11.30 & 11.82 & 10.74 \\
Ether extract (EE) & 2.98 & 3.05 & 3.19 & 3.24 & 9.88 \\
Nitrogen free extract & 67.41 & 66.69 & 65.43 & 64.76 & 47.87 \\
(NFE) & & & & & \\
Ash & 5.78 & 5.83 & 5.88 & 5.93 & 4.58 \\
Fiber fractions \% & & & & & \\
NDF & 37.91 & 37.12 & 35.17 & 34.90 & 37.78 \\
ADF & 22.04 & 24.18 & 22.49 & 21.80 & 19.33 \\
ADL & 2.92 & 4.75 & 4.05 & 3.75 & 3.23 \\
Hemicellulose & 15.87 & 12.94 & 12.68 & 13.10 & 18.45 \\
Cellulose & 19.12 & 19.43 & 18.44 & 18.05 & 16.10 \\
NFC* & 39.28 & 39.90 & 41.56 & 41.68 & \\
\hline
\end{tabular}

*Non fibrous carbohydrates \% = OM \% - (CP\% + NDF\% + EE \%) according to Calsamiglia et al, (1995).

hose reported by O'Shea et al. (2009).

Table (3). Effect of feeding the experimental rations on digestibility coefficients and nutritive values with sheep.

\begin{tabular}{lcccc}
\hline \multicolumn{1}{c}{ Item } & $\mathrm{R} 1$ & $\mathrm{R} 2$ & $\mathrm{R} 3$ & $\mathrm{R} 4$ \\
\hline Digestibility coefficients $\%$ & & & & \\
DM & $66.11^{\mathrm{b}}$ & $66.96^{\mathrm{b}}$ & $69.25^{\mathrm{a}}$ & $68.16^{\mathrm{a}}$ \\
OM & $67.96^{\mathrm{b}}$ & $70.21^{\mathrm{a}}$ & $71.19^{\mathrm{a}}$ & $70.05^{\mathrm{a}}$ \\
CP & $66.44^{\mathrm{d}}$ & $68.36^{\mathrm{c}}$ & $70.52^{\mathrm{a}}$ & $69.18^{\mathrm{b}}$ \\
CF & $61.51^{\mathrm{c}}$ & $62.33^{\mathrm{b}}$ & $63.18^{\mathrm{a}}$ & $62.92^{\mathrm{ab}}$ \\
EE & $77.65^{\mathrm{b}}$ & $77.72^{\mathrm{b}}$ & $79.20^{\mathrm{a}}$ & $79.15^{\mathrm{a}}$ \\
NFE & $71.94^{\mathrm{d}}$ & $73.47^{\mathrm{c}}$ & $74.08^{\mathrm{b}}$ & $75.11^{\mathrm{a}}$ \\
\hline Nutritive values & & & & \\
TDN & $69.15^{\mathrm{c}}$ & $70.41^{\mathrm{b}}$ & $71.31^{\mathrm{a}}$ & $71.71^{\mathrm{a}}$ \\
DCP & $9.33^{\mathrm{c}}$ & $9.64^{\mathrm{b}}$ & $10.01^{\mathrm{a}}$ & $9.86^{\mathrm{ab}}$ \\
TDN : DCP & $7.41^{\mathrm{a}}$ & $7.30^{\mathrm{b}}$ & $7.12^{\mathrm{c}}$ & $7.27^{\mathrm{b}}$ \\
\hline DM, TDN and CP intake $(\mathrm{g} / \mathrm{h} / \mathrm{d})$ & & & & \\
DM & $1050.3^{\mathrm{d}}$ & $1063.6^{\mathrm{c}}$ & $1100.2^{\mathrm{a}}$ & $1082.9^{\mathrm{b}}$ \\
TDN & $726.3^{\mathrm{c}}$ & $749.0^{\mathrm{b}}$ & $784.6^{\mathrm{a}}$ & $776.6^{\mathrm{a}}$ \\
CP & $147.6^{\mathrm{b}}$ & 150.0 & $157.2^{\mathrm{a}}$ & 154.3 \\
\hline
\end{tabular}

$a, b, c$ and $d:$ in the same row with different superscripts are significantly different $(P<0.05)$.

Results concerning nitrogen intake, excretion and nitrogen balance are presented in Table (4). The data indicate no significant differences $(\mathrm{P}<0.05)$ in the daily nitrogen intake $(\mathrm{N} 1)$ between control and diet containing 10\% DDGS, while diets containing DDGS 20 and 30\% recorded higher N1 values with significant differences $(\mathrm{P}<0.05)$. Nitrogen retention $(\mathrm{g} / \mathrm{h} / \mathrm{a})$ was positive in all tested groups indicating that the animals were in normal $\mathrm{N}$ metabolism status. Nitrogen balance was found to be improved due to 
the inclusion of DDGS in the diet of sheep. This may be due to the increase in N digestibility. Similar results were recorded by Peter et al. (2000).

Table (4). Dietary nitrogen utilization of the experimental rations by sheep.

\begin{tabular}{lcccc}
\hline Item & R1 & R2 & R3 & R4 \\
\hline Nitrogen intake $(\mathrm{g} / \mathrm{h} / \mathrm{d})$ & $23.62^{\mathrm{b}}$ & $24.00^{\mathrm{b}}$ & $25.15^{\mathrm{a}}$ & $24.69^{\mathrm{a}}$ \\
Fecal nitrogen $(\mathrm{g} / \mathrm{h} / \mathrm{d})$ & $9.38^{\mathrm{a}}$ & $7.60^{\mathrm{b}}$ & $7.43^{\mathrm{b}}$ & $7.60^{\mathrm{b}}$ \\
Digested nitrogen $(\mathrm{g} / \mathrm{h} / \mathrm{d})$ & $14.24^{\mathrm{b}}$ & $14.40^{\mathrm{b}}$ & $17.62^{\mathrm{a}}$ & $17.09^{\mathrm{a}}$ \\
Urinary N $(\mathrm{g} / \mathrm{h} / \mathrm{d})$ & $10.05^{\mathrm{b}}$ & $11.25^{\mathrm{a}}$ & $11.91^{\mathrm{a}}$ & $11.33^{\mathrm{a}}$ \\
Nitrogen retention $(\mathrm{g} / \mathrm{h} / \mathrm{d})$ & $3.73^{\mathrm{c}}$ & $4.15^{\mathrm{b}}$ & $5.71^{\mathrm{a}}$ & $5.76^{\mathrm{a}}$ \\
N intake \% & 15.80 & 17.29 & 22.70 & 23.33 \\
N digested \% & 26.19 & 28.82 & 32.41 & 33.70 \\
\hline
\end{tabular}

$a, b, c$ means in the same row with different superscripts significantly different $(P<0.05)$.

\section{Rumen parameters:}

Results of ruminal $\mathrm{pH}$, volatile fatty acids (VFA'S) and ammonia nitrogen $\left(\mathrm{NH}_{3}-\mathrm{N}\right)$ are presented in Table (5). Rumen $\mathrm{pH}$ value is one of the most important factors which affect bacterial fermentation in the rumen and influences its functions. Results showed that no significant differences $(\mathrm{P}<0.05)$ among experimental diets on ruminal $\mathrm{pH}$. The obtained values were within the normal ranges $(6.70-6.84)$ as reported by Hungate (1966), who indicated that cellulytic bacteria need a rumen pH of about 6.2 and 7.0 in order to multiply rapidly and colonize the epidermal surfaces of plant fragments, within 5 minute. Means of individual animals exhibited a much narrower range $(6.70-6.84)$. The small decrease in ruminal $\mathrm{pH}$ in the current study may be a result of the residual starch in DDG'S that degraded rapidly in the rumen, and decrease ruminal $\mathrm{pH}$ (Leupp et al., 2009). Regarding the effect of sampling time, the results indicated that the highest value was recorded at zero time and tended to decrease at $3 \mathrm{hrs}$, then returned to increase at $6 \mathrm{hrs}$ post feeding. The data may be related to the fermentation processes of both non-structural and structural carbohydrates and producing of volatile fatty acids.

Table (5). Effect of feeding the experimental rations on some rumen parameters of Rahmany sheep at different times of sampling.

\begin{tabular}{lcllll}
\hline \multicolumn{5}{c}{ Experimental rations } \\
\hline Item & & TMR1 & TMR2 & TMR3 & TMR4 \\
\hline Time of sampling & 0 & 7.18 & 7.09 & 7.05 & 7.03 \\
$\mathrm{pH}$ & 3 & 6.20 & 6.14 & 6.08 & 6.03 \\
& 6 & 7.15 & 7.07 & 7.09 & 7.03 \\
& Mean & 6.84 & 6.77 & 6.74 & 6.70 \\
$\mathrm{NH}_{3}-\mathrm{N}$ (mg/100 ml) & 0 & 12.90 & 12.11 & 12.03 & 11.35 \\
& 3 & 16.60 & 15.0 & 14.30 & 13.61 \\
& 6 & 12.81 & 12.20 & 12.03 & 11.55 \\
TVFA'S (mmol/100 ml)0 & $14.10^{\mathrm{a}}$ & $13.11^{\mathrm{b}}$ & $12.79^{\mathrm{b}}$ & $12.17^{\mathrm{c}}$ \\
& 3 & 8.75 & 6.91 & 7.41 & 7.55 \\
& 6 & 6.02 & 9.31 & 10.21 & 10.71 \\
& Mean & $6.63^{\mathrm{C}}$ & 6.85 & 7.41 & 8.12 \\
& & $7.69^{\mathrm{b}}$ & $8.34^{\mathrm{a}}$ & $8.79^{\mathrm{a}}$ \\
\hline
\end{tabular}

$a, b, c$ means in the same row with different superscripts are significantly differ $(P<0.05)$.

The volatile fatty acids were increased with proceeding time and cause a reduction in ruminal $\mathrm{pH}$, until they were proportionally more absorbed from the rumen wall, resulting the present increase in $\mathrm{pH}$. The present results agree with the findings of Reddy and Reddy (1985); El-Shinnawy (2003, 2010) and El- Shinnawy et al. (2011).

Ammonia-N concentration was greater for control diet which is due to the higher degradable protein concentration of this diet. There was a linear decrease in ammonia-N concentration as the level of DDG'S increased in diets containing 10, 20 and 30\% DDG'S. This result may be due to the replacement of yellow corn and soybean meal with DDG'S which resulted in lower of degradable crude protein in the 
rumen. This result is in agreement with that obtained by Anderson et al. (2006) who found a significant decrease in ammonia- $\mathrm{N}$ concentration with DDG'S feeding. In this respect, Firkins et al. (1984) reported that soybean meal protein was more degradable than corn distiller grains protein in the rumen. Mc Carthy et al. (1989) reported that 5 to $6 \mathrm{mg} / \mathrm{dl}$ of ammonia is adequate to stimulate microbial protein synthesis. In the present study, ruminal ammonia concentration of diets containing DDG'S were 13.11, 12.95 and 12.77 of TMR 2, 3 and 4, respectively. These amounts of ammonia are adequate enough to allow maximum microbial protein synthesis.

The results showed that the overall mean of TVFA'S concentration was lower significantly $(\mathrm{P}<0.05)$ for rams fed control ration, while there was no significant difference between TMR3 and TMR4 fed rations containing DDG'S. Supplemented with DDG'S showed significant increase in total TVFA'S concentrations than control. These results are in agreement with those obtained by Soliman et al. (2013) who found linear increase of total VFA'S with increasing DDGS supplementation amount.

\section{Blood parameters:}

Blood represents an important index of physiological, pathological and nutritional status of the organism. Changes in the constituent compounds of blood, when compared to the normal values, could be used to interpret the metabolic status of the animal and perhaps nutrient adequacy of feed consumed (Nworgu et al., 2007).

Data presented in Table (6) showed that increasing level of DDGS in diets of calves increased TP concentrations, being the lowest in TMR1 (control). The normal range of TP was reported by kancko (1989) to be 6.0- $7.9 \mathrm{mg} / \mathrm{dl}$ while, Jawasreh et al, (2010), showed that it was 5.9- $7.8 \mathrm{mg} / \mathrm{dl}$. Albumin and globulin concentrations for animals fed the experimental rations, containing DDGS recorded insignificant difference.

Higher concentration of serum total protein may be attributed to improve nitrogen absorption (Kornegay et al., 1997). The values of AST were higher significantly $(\mathrm{P}<0.05)$, with rations containing DDGS than that of the control (Table 6).

Baranowski et al. (2000) found that there is a positively correlation between body weight and AST. Serum ceratinine and cholesterol mean values were not affected by fed treatment rations. The values obtained here in were within the normal range for healthy sheep for cholesterol (Saleh \& Saleh 2003) and creatinine (Jawasreh et al., 2010). Results obtained were similar with those reported by Etman et al. (2010).

Generally, the obtained results concerning blood parameters studied indicated normal physiological and healthy status of all experimental calves.

Table (6). Effect of feeding the experimental rations on some blood serum parameters of buffalo's calves as affected by experimental rations.

\begin{tabular}{lcccc}
\hline Measurements & TMR1 control & TMR2 & TMR3 & TMR4 \\
\hline Total protein (g/dl) & $6.45^{\mathrm{c}}$ & $6.75^{\mathrm{b}}$ & $6.79^{\mathrm{b}}$ & $7.28^{\mathrm{a}}$ \\
Albumin (g/dl) & 3.55 & 3.61 & 3.63 & 3.68 \\
Globulin (g/dl) & 2.90 & 3.14 & 3.16 & 3.60 \\
A/G ratio \% & 1.82 & 1.87 & 1.87 & 1.98 \\
AST (U/L) & $24.15^{\mathrm{c}}$ & $27.33^{\mathrm{b}}$ & $28.11^{\mathrm{b}}$ & $30.10^{\mathrm{a}}$ \\
ALT (U/L) & 15.77 & 16.11 & 16.22 & 15.91 \\
AST/ ALT ratio (\%) & 1.53 & 1.70 & 1.74 & 1.89 \\
Ceratinine (mg/dl) & 1.29 & 1.18 & 1.15 & 1.25 \\
Cholesterol (mg/dl) & 128.13 & 126.71 & 127.33 & 127.81 \\
\hline
\end{tabular}

$a, b, c$ in the same row with different superscripts significantly differ $(P<0.05)$.

\section{Growth performance:}

Results obtained in Table (7) indicated that group fed on control ration recorded significantly (P< 0.05 ) lower body weight gain than groups fed on rations containing 10\%, 20\%, and 30\% DDGS. Total body gain and daily gain were increased $(\mathrm{P}<0.05)$ with increasing replacement of DDG'S. Average daily gain was increased by $16 \%, 21 \%$ and $23 \%$ for calves fed rations containing $10 \%, 20 \%$ and $30 \%$ DDG'S, respectively, than that of control.

These results are in agreement with those obtained by Berger and Ferkins (1985). They observed that steers fed DDGS grow more rapidly and were more efficient than those fed corn-gluten diet. Felix et al. (2012) reported that lambs fed the $20 \%$ DDGS diet had the greatest gain. On the contrary, Leupp et al. 
(2009) found that ADG was not affected when fed steers on $30 \%$ distillers dried grains with soluble. Similar results were reported by Wood et al. (2011), who reported that supplement of $200 \mathrm{gm}$ DDG 'S/Kg diet to crossbred steer did not affect daily gain on average.

Table (7). Growth performance of buffaloes as affected by feeding TMR containing different levels of DDGS.

\begin{tabular}{lcccc}
\hline Items & \multicolumn{3}{c}{ Experimental rations } \\
\cline { 2 - 4 } & TMR1 & TMR2 & TMR3 & TMR4 \\
\hline Initial live body weight, kg & 204.5 & 202.3 & 201.2 & 201.1 \\
Final live body weight, kg & $368.9^{\mathrm{c}}$ & $392.6^{\mathrm{b}}$ & $3998^{\mathrm{a}}$ & $402.6^{\mathrm{a}}$ \\
Total body weight gain, kg & $164.4^{\mathrm{c}}$ & $190.3^{\mathrm{b}}$ & $198.6^{\mathrm{a}}$ & $201.5^{\mathrm{a}}$ \\
Daily gain, kg & $0.913^{\mathrm{c}}$ & $1.057^{\mathrm{b}}$ & $1.103^{\mathrm{a}}$ & $1.119^{\mathrm{a}}$ \\
Feed intake, kg/h/day & 9.350 & 9.500 & 9.610 & 9.650 \\
Total DM1, Kg/h/day & $8.369^{\mathrm{d}}$ & $8.486^{\mathrm{c}}$ & $8.567^{\mathrm{b}}$ & $8.628^{\mathrm{a}}$ \\
Total digestible nutrients kg/h/day & 5.787 & 5.975 & 6.109 & 6.187 \\
Total DCP, Kg/h/day & 0.781 & 0.818 & 0.858 & 0.851 \\
Feed conversion & & & & $7.710^{\mathrm{c}}$ \\
DM1/daily gain & $9.166^{\mathrm{a}}$ & $8.028^{\mathrm{b}}$ & $7.770^{\mathrm{c}}$ & $5.529^{\mathrm{c}}$ \\
TDN intake/ daily gain & $6.338^{\mathrm{a}}$ & $5.633^{\mathrm{b}}$ & $5.538^{\mathrm{c}}$ & $0.715^{\mathrm{c}}$ \\
DCP intake/ daily gain & $0.855^{\mathrm{a}}$ & $0.774^{\mathrm{b}}$ & $0.778^{\mathrm{b}}$ & \\
\hline
\end{tabular}

$a, b, c$ means in the same row, with different superscripts are significantly differ $(P<0.05)$.

Data in the present study show that DDG'S replacement has non-significant increase in total dry matter intake. Similar results were reported by Huls et al. (2006) who reported that no positive or negative effect for DDG'S replacement by $23 \%$ on DMI. In contrast Soliman and Ghada El Ashry (2012) indicated that incorporate DDG'S at levels of 10,20 or $30 \%$ in sheep rations increased DM intake.

Feed conversion expressed as $\mathrm{Kg} \mathrm{DM} / \mathrm{Kg}$ gain showed that the calves fed diets containing $30 \%$ DDG'S, recorded the best values (7.710) followed by $20 \%$ DDG'S (7.770), while the worst value was recorded with the control ration. The same trend was observed with TDN and DCP. These results are in agreement with those obtained by soliman and Ghada El Ashry (2012) who reported positive effect for DDG'S replacement by 10,20 , or $30 \%$ on feed conversion with sheep.

\section{Economic efficiency:}

The profitability of using DDGS in growing and finishing diets of buffalo calves depends on the cost of these ingredients and their effect on growth performance.

Data presented in Table 8, show that lowest cost/ kg body weight gain (17.63 LE), was observed with calves fed 30\% DDGS followed by those fed $20 \%$ level (18.20 LE), while the highest (22.53 LE), was recorded with control group (zero DDGS).

Table (8). Economic evaluation of buffalo calves as affected by feeding TMR containing different levels of DDGS.

\begin{tabular}{lcccc}
\hline Items & \multicolumn{4}{c}{ Experimental rations } \\
\cline { 2 - 4 } & TMR1 & TMR2 & TMR3 & TMR4 \\
\hline Feed intake, kg/h/day & 9.350 & 9.500 & 9.610 & 9.650 \\
Feed cost, LE/h/day & 20.570 & 20.380 & 20.080 & 19.730 \\
Initial live body wt, kg & 204.500 & 202.300 & 201.200 & 201.100 \\
Final live body wt, kg & 368.900 & 392.600 & 399.800 & 402.600 \\
Total body wt. gain, kg & 164.400 & 190.300 & 198.600 & 201.500 \\
Daily gain, kg & 0.913 & 1.057 & 1.103 & 1.119 \\
Feed cost, LE/kg gain & 22.530 & 19.280 & 18.200 & 17.630 \\
Net revenue, LE & 5.470 & 8.720 & 9.800 & 10.370 \\
Economic efficiency & 0.270 & 0.430 & 0.490 & 0.520 \\
Relative economic efficiency & 0.100 & 0.159 & 0.179 & 0.190 \\
\hline Free
\end{tabular}

Free market prices (LE/ ton) for feed ingredients used in formulating the TMR in the year (2015).

Yellow corn 1800, soybean meal 3700, wheat bran, 1800; DDGS, 2200; Berseem hay, 1600; Molasses, 700; Salt, 2oo; Lime stone, 100; Premix, 3000 and add 100 LE for mixing.

Price $/ \mathrm{kg}$ live wt. $(L E)=28$. 
This may be due to include DDGS in the diets scored better, body weight, weight gain, besides best feed conversion.

Average economic efficiency values of different dietary treatments ranged between 0.27 and 0.52 , being the best for calves fed the higher level of DDGS (30\%) compared to the worst values by calves fed the control ration. Relative economic efficiency increased as the level of DDGS increased in calves diets, compared to the control.

Therefore, replacing 10, 20 and 30\% of soybean and yellow corn by DDGS can be used in buffalo calves diets to get better feed cost per kg daily gain, net revenue and economic efficiency. Generally, it may be shown that, inclusion of DDGS with a rate of $30 \%$ in buffalo calves diets tended to economical effectiveness.

\section{CONCLUSION}

Conclusively, according to the circumstances of this study, it could be recommended that replacement up to $30 \%$ of soybean meal and yellow corn by dried distiller grains with soluble (DDGS) in growing and finishing buffalo calves diet is a good source realized improvement in all digestion coefficients, nutritive values and rumen fermentation activity, also increased total body weight gain and average daily gain as well as improved the economic efficiency without adverse effect on health of buffalo calves.

\section{REFERENCES}

Al-Rabbat, M.F.; Bald win and W.C. Weir (1971). In vitro nitrogen-treacer technique for some kinetic measures of rumen ammonia. J. Dairy Sci., 54:150.

Anderson, J.L.; D.J. Schingoethe; K.F. Kalscheur and A.R. Hippen (2006). Evaluation of dried and wet distillers grains included at two concentrations in the diets of lactating dairy cows. Journal of Dairy Science, 89:3133-3142.

A.O.A.C. (1995). Official Methods of Analysis (15 $5^{\text {th }}$ Ed.). Association official Analytical Chmists. Washington, Virginiall, USA.

Baranowski, P.; S. Baranowski and W. Klata (2000). Some hematological and biochemical serum and bone tissue indices of lambs derived from ewes fed on vitamin and mineral- vitamin supplements during pregnancy. Bull. Vet. Inst. Pulawy, 44:207-214.

Bartels, H. (1971). Colorimetric determination of creatinine. Chem. Acta, 32:81.

Berger, L. L. and J. L. Ferkins (1985). Corn gluten feed for beef cattle. Proc. Corn gluten feed for 1he livestock industry- Iowa State University Extension, pp 1-8.

Calsamiglia, S; M.D. Sterm and and J.L. Firkins (1995). Effect of protein source on nitrogen metabolism in continuous culture and intestine digestion in vitro. J. Anim. Sci., 7:1819.

Choi, H.S; H.L. Lee; M.H. Shin; J.O. Chrorum; S.K. Lee and B.D. Lee (2008). Nutritive and economic values of of corn distillers dried grains with soluble in broiler diets, Asian- Australasian. J. Anim. Sci., 21, 414-419.

Doumas, B.T.; W.A. Watson and H.G. Biggs (1971). Albumin standards and the measurement of serum albumin with bromcresol green. Clin. Chim. Acta, 31: 87-96.

Duncan, D. B. (1955). The multiple Range and Multiple F-test. Biometrics, 11:1-42.

El- Shinnawy, A.M. (2010). Banana plant wastes as untraditional feed source for rahmany sheep. Ph.D. Thesis, Fac. Agric., Univ., Egypt.

El- Shinnawy, A.M. (2003). Studies on silage in ruminant feeding. M. SC. Thesis, Fac. Agric. Univ., Egypt.

El- Shinnawy, M.M.; M.F. Emara; H.F.A. Motawe; Fatma, M. Salman and A.M. El-Shinnawy (2011). Effect of two kinds of bacteria inoculants on preservation and nutritive values of vine broad bean silages, compared with clover hay. Proc. Of the $4^{\text {th }}$ Animal Welth Research conf. in the middle East $\&$ North Africa. 
Etman, K.E.I.; A.M.M. Zeid and T.I. EL- Monayer (2010). Utilization from new national resources in ruminant feeding: 1. Effect of using dried distillers grains with solubles (DDGS) in ratios for fattening Friesian calves. J. Animal and Poultry Prod., Mansoura Univ., Vol. 1(12): 659-668.

Felix, T.L.; F.L. Fluharty; W.P. Weiss and S.C. Loerch. (2012). Effects of copper supplementation on performance, carcass characteristics, and rumen parameters of growing cattle fed diets containing $60 \%$ DDGS. J. Anim. Sci., 90:2710-2716.

Firkins, J.L.; L.L. Berger; G.C. Fahey and J. R. Merchen (1984). Ruminal nitrogen degradability and escape of wet and dry distillers grains and wet and dry corn gluten feeds. Journal of dairy Science. 67:1936-1944. Croo Ref., Web of Science@Times Cited: 9.

Kaneko, J.J. (1989) Clinical Chemistry of Domestic Animals. $4^{\text {th }}$ Ed. Academic Press, Inc., 886-891.

Fossati, P. and L. Prencipe (1982). Serum Triglycerides Determined Colorimetrically with an Enzyme that Produces Hydrogen Peroxide. Clinical Chemistry, 28, 2077-2080.

Gilbery, T.C.; G.P. Lardy, S.A. Soto-Navarro; M.L. Bauer and J.S. Caton (2004). Effects of corn condensed distillers solubles supplementation on ruminal fermentation, digestion, and in situ disappearance in steers consuming low-quality hay. J. Anim. Sci., 2006. 84:1468-1480.

Hach, R.H. (1993). Distillers feeds, grains are good source of feed protein. Feedstuff, 65(34):14.

Huls, T.J.; A.J. Bartosh; J.A. Daniel; R.D. Zelinsky; J. Held and A.E. Wertz-Lutz. (2006). Efficacy of dried distiller's grains with solubles as a replacement for soybean meal and a portion of the corn in a finishing lamb diet. Sheep and Goat Research Journal. 21: 30-34.

Hungate, R.E. (1966). The rumen and its microbes. Academic pree, Inc., Ny., NY., USA, 533.

Jawasreh K.; F. Awawdeh; Z. Bani Ismail; O. Al-Rawashdeh and A. Al- Majali (2010). Normal Hematologyand Selected SerumBiochemical Values in Different Genetic Lines of Awassi Ewes in Jordan. The International Journal of Veterinary Medicine, 7 (2). DOI: 10.5580/c27.

Kleinschmit, D.H.; D.J. Schingoethe; K.F. Kalscheur and A.R. Hippen (2006). Evaluation of various sources of corn dried distillers grains plus solubles for lactating dairy cattle. J. Dairy Sci., 89:47844794.

Kornegay E.T.; Z. Wang; C.M. Wood and M.D. Lindemann (1997). Supplemental chromium picolinate influences nitrogen balance, dry matter digestibility and carcass traits in growing-finishing pigs. J. Anim. Sci., 75:1319-1323.

Leupp, J.L.; G.P. Lardy and J.S. Caton (2012). Effects of supplying increasing levels of Distillers Dried Grain with Solubles in Growing Diets on Intake. Digestion and Ruminal Fermentation. Nebraska Beef Cattle Report. MP88-A. Univ. of Nebras Ka, Lincoln.

Leupp, J.L.; G.P. Lardy; K.K. Karges; M.L. Gibson and J.S. Caton. (2009). Effects of increasing level of corn distillers dried grains with solubles on intake, digestion, and ruminal fermentation in steers fed seventy percent concentrate diets. J. Anim. Sci., 87:2906-2912.

Liu, C.; D.J. Schingoethe and G.A. Stegeman (2006). Influence of distillers dried grains with solubles (Starprot) in dairy cow feeding. Slovak J. Anim. Sci., 39(1-2):43-50.

Lumpkins, B.S.; A.B. Batal and N.M. Dale (2004). Evaluation of distiller's dried grains with solubles as a feed ingredient for broiler chickens. Poult. Sci., 83:1891-1896.

Mc Carthy, R.D.; T.H. Klusmeyer; J.L. Vicini; J.H. Clark and D.R. Nelson. (1989). Effects of source of protein and carbohydrate on ruminal fermentation and passage of nutrients to the small intestine of lactating cows. J. Dairy Sci., 72: 2002-2016.

NRC, (1985). Nutrients Requirements of sheep feeds for ruminants. J. Anim. Sci., 60-847-860, 1985. (6 ${ }^{\text {th }}$ Reu. Ed) National Academy. Press, Washington, DC.

NRC, (2000). Nutrients Requirements of Beef Cattle. $7^{\text {th }}$. Ed Nath. Acad. Press, Washington, DC.

Nworgu, F.C.; S.A. Ogungbenro and K.S. Solesi (2007). Performance and some blood Chemistry indices of broiler chicken served fluted pumpkin (Telfaria occidentalis) leaves extract supplement. Am. Eurasian J. Agric. Environ. Sci., 2 (1): 90-98. 
O'Shea, C.J.; B. Lynch; M.B. Lynch; J.J. Callan and J.V. O'Doherty (2009). 'Ammonia emissions and dry matter of separated pig manure fractions as affected by crude protein concentration and sugar beet pulp inclusion of finishing pig diets'. Agriculture, Ecosystems and Environment, 131 (3-4):154-160.

Pavan, E.; S.K. Duckett and J.G. Andrae. (2007). Corn oil supplementation to steers grazing endophytefree tall fescue. I. Effects on in vivo digestibility, performance, and carcass traits. J. Anim. Sci. 85: 1330-1339.

Peter, C.M.; D.B. Faulkner; N.R. Merchen; D.F. Parrett; T.G. Nash, and J.M. Dahlquist (2000). The Efects of Corn Milling Co-Products on Growth Performance and Diet Digestibility by Beef Cattle. J. Anim. Sci., 78:1-6.

Powers, W.J.; H.H. Van Horn; B. Harris, Jr. and C.J Wilcox (1995). Effects of variable sources of distillers dried grains plus solubles on milk yield and composition. J. Dairy Sci., 78:388-396.

Reitman, S. and S. Frankel (1957). A colorimetric method for the determination of serum glutamic oxalacetic and glutamic pyruvic transaminases. Am. J. Clin. Pathol., 28: 56-63.

Reddy, K.J. and M.R. Reddy (1985). Effect of feeding complete feeds on various nitrogen fraction and total volatile fatty acid concentration in the rumen fluid of sheep. Inidan J. Anim. Sci., 55 (99): 819825.

Robertson, J.B. and P.J. Van Soest (1981). The detergent system of analysis and its application to human foods. in: W.P.T. James, O. The ender (Eds.) The analysis of dietary fiber in foods. Marcel Dekker, New York, NY; 1981:123.

Saleh, Safaa A. and H.M. Saleh (2003). Studies on performance of male lambs fed on ration containing AD3A- Al- Azhar J. Agric- Res., 37: 235-248.

SAS (2003). SAS/Start User's Guide Statistics. Ver. 91- SAS institute Inc. Cary NC, USA.

Schawer, C.S.; M.M. Stamm; T.D. Maddock and P.B. Berg (2008). Feeding of DDGS in lamb rations feeding dried distillers grains with solubles as 60 percent of lamb finishing rations results in acceptable performance and carcass quality. Sheep \& Goat Research Journal, 23: 15-19.

Soliman, M.S. and Ghada M. El- Ashry (2012). Effects of different levels of distillers dried grains on nutritive values and growth performance in sheep. The Egyptian Science Magazine, 7 (5): 79-91.

Soliman, M.S. and Gada M. El- Ashry and A.M. EL Okazy (2013). Evaluation of corn distillers dried grain with solubles in ruminant rations and its effect on milk production. J. Animal and poultry prod. Mansoura Univ., 4(11): 599-614.

Spiehs, M.J.; M.H. Whitney and G.C. Shurson (2002). Nutrient database for distiller's dried grains with solubles produced from new ethanol plants in Minnesota and South Dakota. J. Anim. Sci., 80:26392645.

Stein, H.H. and G.C. Shurson (2009). BOARD-INVITED REVIEW: The use and application of distillers dried grains with solubles in swine diets. J. Anim. Sci., 87:1292-1303.

Trinder, P. (1969). Determination of glucose. Enzymatic method. Ann. Clin. Biochem., 6-24.

Van Soest, P.J. and W.C. Marcus (1964). Methods for the determination of cell wall constituents in forages using detergents and the relationship between this fraction and voluntary intake and digestibility. J. Dairy Sci., 47:704.

Warner, A.C.I. (1964). Production of volatile fatty acids in the rumen: methods of measurement. Nutr. Abstr. Rev., 34: 339-352.

Warner, R.G. (1970). The place of distillers feeds in dairy rations - a review. Proc. Dist. Feed Res. Council, 25:11-18.

Weichsel baum, F. (1989). Colorimetric determination of total protein. Am. J. Cli. Path., 16: 40.

Wood, K.M.; H. Salim; P.L. McEwen; I.B. Mandell; S.P. Miller and K.C. Swanson (2011). The effect of corn or sorghum dried distillers grains plus solubles on growth performance and carcass characteristics of cross-bred beef steers. Anim. Feed. Sci. Tech., 165:23-30. 
تأثير إحلال مستويات مختلفة من النواتج الثانوية لتقطير الحبوب محل كسب فول الصويا وجزء من الأذرة في عليقة نمو وتسمين العجول الجاموسي

محمد محمد الثناوى1،كامل عتمان ابراهيم²، جيهان محمد المغازى و واحمد محمد الثناوى3

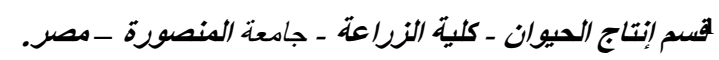

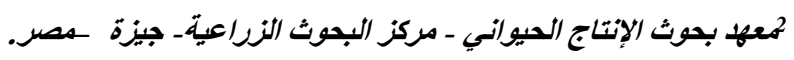

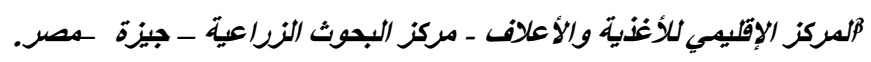

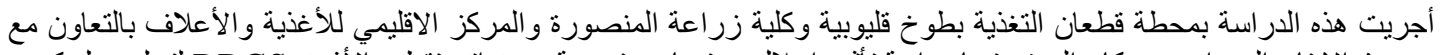

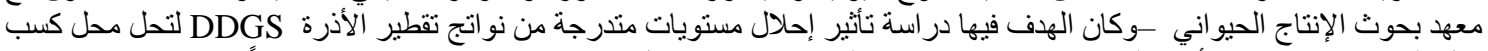

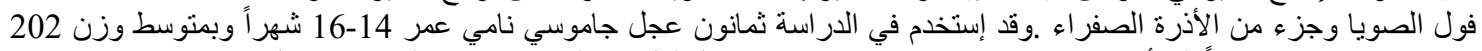

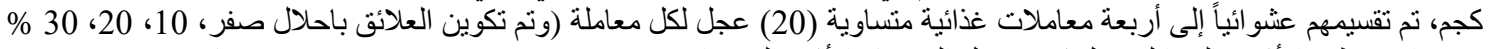

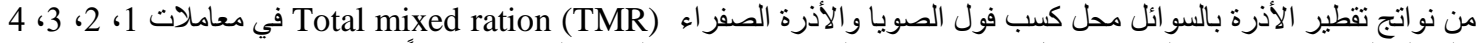

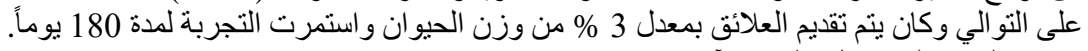
وكانت النتائتج المتحصل علئيها كالآتي :

إنخفاض معنوى عند مستوى (5\%) في وزن الجسم ومعدل النمو اليومي في العجول المغذاه على عليقة المقارنة بينما سجلت

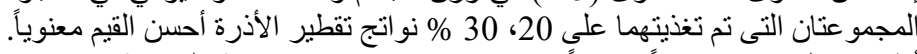

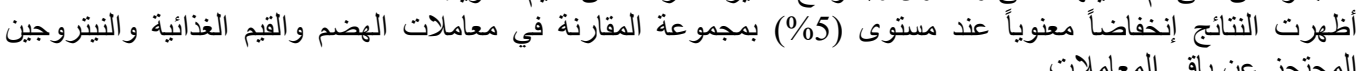
لم يكن هناك إختلافات معنوية عند مستوى (5\%) (5) في درجة حموضة الكرش وكانت القيم المتحصل عليها في المدى الطبيعى. (6.70-6.84)

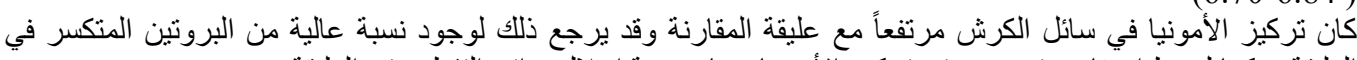

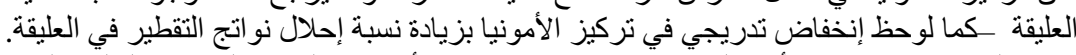

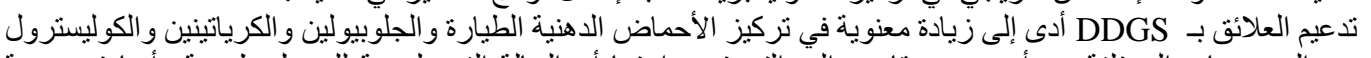
بين المجموعات المختلفة ـوأوضحت مقاييس الدم التى تم دراستها أن الحالة الفسيولوجية للعجول طبيعية وأنها في صحة

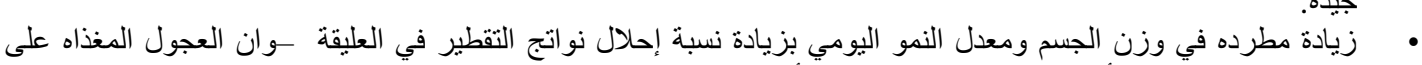
عليقة تحتوى على 20 أو 30\% نو اتج تقطير حققت أحسن معدل تحويل غذائي.

وخلصت النتائج إلى أن تضمين العلائق بنو اتج تقطير الحبوب بنسبة 30\% بداًاً من كسب فول الصويا والأذرة الصفراء في علائق

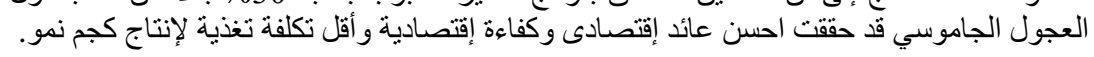

